\title{
WYKORZYSTANIE RYNKU PRZEZ POLITYKĘ EKOLOGICZNĄ
}

\section{Streszczenie}

Celem artykułu jest przedstawienie możliwości zwiększenia wykorzystania rozwiązań rynkowych w polityce ekologicznej. W szczególności dotyczy to działania na rzecz zrównoważonej produkcji i konsumpcji. W pierwszej części omówiono postawy polityki ekologicznej wobec rynku, tj. postawy: kreacji, integracji, kooperacji, obserwacji, stymulacji/wspierania prośrodowiskowego przekształcania rynku, zaniechania oraz ignorowania. W drugiej części artykułu wskazano na potrzebę stosowania instrumentów rynkowych przez politykę ekologiczną w celu wspierania zrównoważonej produkcji i konsumpcji.

Słowa kluczowe: polityka ekologiczna, rynek, regulacja, rozwój zrównoważony

\section{USING MARKET FOR ENVIRONMENTAL POLICY}

\section{Summary}

This paper aims to identify the opportunities for increasing the use of market-based solutions in environmental policies. In particular, this applies to actions for sustainable production and consumption. The first part discusses environmental policy attitudes towards the market. These include the attitudes of creation, integration, cooperation, supervision, stimulation/support for pro-environmental transformation of the market, non-action and ignoring. In the second part of the paper, the author points out the need for an environmental policy of market-based instruments to support sustainable production and consumption.

Key words: environmental policy, market regulation, sustainable development

JEL: Q58, H23, Q56, K32

\section{Wstęp}

W raporcie „Środowisko Europy 2015” stwierdzono, że w wielu driedzinach efektywność wykorzystania zasobów ulega poprawie - spoteczeństwo znajduje sposoby na zwiekeszenie produkeji i koryyśsi ekonomicznych w porównaniu do wywieranych presji na środowisko. Jednak w wiekeszości praypadkón nie wydaje sie prawdopodobne, aby te zmiany doprowadzity do realizacji wi zji gospodarki 
UE do roku 2050, w której gospodarowanie wssystkimi zasobami, od surowcón po energie, wode, powietrze, ziemię i glebe, jest rrównowažone [Środowisko Europy..., 2015, s. 52-53]. Jako jeden $\mathrm{z}$ wniosków podaje się, że trzeba uyjsść poza izolowane problemy poprany efektywności i zamiast tego nalešy zajać sie w sposób zintegrowany systemami produkcji i konsumpcji, ketóre zapewniaja potrzeby spoteczne. (...) Perspektywa taka zakłada skoncentrowanie sie nie tylko na wykoryystaniu konkretnych zasobów cay materiatón, ale także skeupienie sie na systemach spotecznych, gospodarcaych i środowiskonych, które determinuja uìytkowanie zasobów przez spoteczeństwo [Środowisko Europy..., 2015, s. 52-53].

Rynek jest tym, co w możliwie najszerszym zakresie integruje te systemy. W większości współczesnych państw gospodarka rynkowa kształtuje się pod dużym wpływem państwa. Polityka rządowa może w znacznym stopniu oddziaływać na rynek, tym samym na decyzje podmiotów.

Każdy z systemów jest regulowany przez politykę rządowa - gospodarcza, społeczną i ekologiczna. Wykorzystanie narzędzi rynkowych w każdej z nich jest niejednakowe - najszersze w zakresie gospodarki, a najwęższe w dziedzinie środowiska. Celem artykułu jest przedstawienie możliwości zwiększenia stosowania rozwiązań rynkowych w polityce ekologicznej.

W pierwszej części artykułu zidentyfikowano i opisano możliwe nastawienia/postawy wobec rynku, które występują w polityce ekologicznej. W drugiej części artykułu wskazano na możliwości zastosowania rozwiązań rynkowych w działaniach polityki ekologicznej na rzecz zrównoważonej produkcji i konsumpcji.

\section{Postawy polityki ekologicznej wobec rynku}

Rynkowa orientacja polityki ekologicznej jest ideą o charakterze deklaratywnym. Jednak w praktyce pojawiają się konkretne wyzwania i problemy, które są związane z istnieniem lub powstawaniem rynków. W polityce ekologicznej wobec takich problemów można stosować różne nastawienia, które dalej określono jako postawy. Można więc wyróżnić postawy:

- kreacji,

- integracji,

- kooperacji,

- obserwacji,

- stymulacji/wspierania prośrodowiskowego przekształcania rynku,

- zaniechania,

- ignorowania.

\section{Postawa kreacji}

Polityka ekologiczna może kreować nowe rynki. W zasadzie działalność ta dotyczy tych obszarów polityki ekologicznej, dla których nie istniały dotąd rynki albo występowały błędy rynku. Nie oznacza to, że w obszarach tych brakowało regulacji ze strony 
polityki ekologicznej. Regulacja taka zwykle istnieje i może mieć charakter czysto administracyjny lub administracyjny z dodatkiem instrumentów ekonomicznych. W przypadku regulacji administracyjnej prawnie dozwolona eksploatacja środowiska, w tym: jego zanieczyszczanie, zakresy i warunki korzystania z zasobów, walorów i funkcji środowiska przyrodniczego, jest określona przez pozwolenia prawno-administracyjne, standardy (normy), nakazy i zakazy oraz inne środki regulacji bezpośredniej.

Kreowanie rynków ma więc być sposobem na realizację celów polityki ekologicznej w warunkach otoczenia rynkowego i z wykorzystaniem instrumentów i mechanizmów zgodnych z zasadami funkcjonowania gospodarki rynkowej. Rynki takie nie są w stanie powstawać spontanicznie czy samorzutnie. Należy je stworzyć i sprawić, że będą funkcjonowały w zgodzie z zasadami i prawami rynkowymi.

Minister właściwy do spraw środowiska prowadzi politykę ekologiczną w zakresie określonym przez ustawy. Możliwości tworzenia przez niego nowych rynków obejmuja zasoby i walory środowiska, jak również oddziaływania na środowisko występujące w ramach różnych form działalności podmiotów. Kreacja rynków może dotyczyć szerokiego spektrum zagadnień. Mogą to być rynki odnoszące się do kwestii uregulowanych za pomocą rozwiązań prawno-administracyjnych, z zastosowaniem lub nie instrumentów ekonomicznych. Przykładem są rynki tworzone w celu regulacji zanieczyszczeń powietrza, wód, kwot połowowych itp. Rynki mogą być także kreowane celem rozwiazzania problemów, które w niewielkim stopniu są uregulowane innymi formami rozwiazzań, na przykład: kompensaty przyrodniczej, odpadów czy, szeroko rozumianej, internalizacji ekologicznych kosztów zewnętrznych. Wprawdzie na świecie istnieja już próby zastosowania rynków dotyczących tej kwestii, ale są mało rozpowszechnione. Dlatego można przyjąć, że są to nowe obszary związane z regulacją rynkowa problemów podlegających gestii ministra środowiska.

Wspólną cechą dotyczącą kreacji rynków jest tworzenie mechanizmu wdrażania celów polityki ekologicznej w obszarach bezpośrednio podległych ministrowi środowiska. W ten sposób dla ustalonych celów polityki ekologicznej tworzy się i wdraża mechanizmy rynkowe zorientowane bezpośrednio na cele własne tej polityki. To minister jest inicjatorem i kreatorem. Udział innych podmiotów, a w szczególności ministrów innych resortów, jest nawet wskazany, ale inicjatywa i ostateczny kształt przyjętych rozwiązań powinien należeć do ministra środowiska.

Charakterystyczne dla tego typu postawy jest także ujęcie problemów w układzie poszczególnych komponentów środowiska - powietrza lub określonych jego zanieczyszczeń: wody, gleby, przyrody ożywionej czy nieożywionej itd., to znaczy w ujęciu medialnym (mediów środowiska). Możliwe jest również ujęcie procesowe - rynek dla specyficznych procesów powodujących zagrożenia środowiska. Natomiast ujęcie sektorowe - pod względem rodzajów działalności albo produktowe - pod względem rodzaju wytwarzanych produktów czy usług są w podejściu kreacji rynków mało prawdopodobne.

\section{Postawa integracji}

Polityka ekologiczna i inne polityki mogą mieć cele, które mają wiele wspólnego ze sobą lub nawet są całkowicie zbieżne. Przykładem tego typu sytuacji jest rozwój 
odnawialnych źródeł energii kreowany przez politykę energetyczną i wspólny z celami polityki ekologicznej, pod warunkiem że nie prowadzi do nadmiernego zubożenia środowiska przy eksploatacji wspólnych zasobów. Polityce energetycznej przyświeca cel ograniczenia zależności od kopalnych nośników energii, natomiast w rozwoju odnawialnych źródeł energii dostrzega ona szansę na zmniejszenie emisji zanieczyszczeń do powietrza. Podobna zbieżność celów polityki energetycznej i ekologicznej występuje w popieraniu działań na rzecz zwiększania efektywności energetycznej. Zbieżność celów ma miejsce w przypadku dążenia do ograniczania przesadnych przewozów bądź przejazdów w polityce transportowej oraz nadmiernych emisji zanieczyszczeń powietrza i hałasu w polityce ekologicznej.

Dla dwóch (lub więcej) polityk współdziałanie jest korzystne. Mogą one uzgadniać nie tylko cele, ale także instrumenty i mechanizmy współpracy. Polityki odnoszące się do branż czy gałęzi, w których dużą rolę odgrywa konkurencja i rynek, będą zainteresowane tworzeniem układów rynkowych, które prowadzą do rozwiązywania ich problemów, a jednocześnie w sposób pozytywny oddziałują na efekty polityki ekologicznej. Tym samym rynek tworzony na potrzeby innej polityki jest dla polityki ekologicznej narzędziem realizacji jej własnych celów. Lepiej zatem integrować działania na rzecz powstania rynku z inną polityką niż pozostawić tego typu działania tej polityce.

W krajach OECD stosuje się dwa typy mechanizmów instytucjonalnego współdziałania ${ }^{1}$ :

- „pionowy” (między różnymi administracyjnymi poziomami);

- „poziomy” (między kompetentnymi władzami na tym samym poziomie władzy administracyjnej).

W tego typu układach typowe powinno być ujęcie procesowe i produktowe.

\section{Postawa kooperacji}

Polityka ekologiczna ma szczególne usytuowanie wśród innych polityk. Z jednej strony może być uznawana za politykę o charakterze sektorowym, ponieważ zajmuje się konkretnym obszarem funkcjonowania gospodarki, którego zakres można wyraźnie określić. Z drugiej strony ma charakter horyzontalny, gdyż zasoby i walory środowiska znajduja zastosowanie w niemal każdej aktywności gospodarczej i społecznej. Zwłaszcza w tym ostatnim - szerokim rozumieniu miejsca polityki ekologicznej wśród innych polityk - polityka ekologiczna musi tworzyć relacje z innymi politykami.

W stosunku do nich może ona być traktowana jako czysto usługowa - zapewniać dostawę niezbędnych dóbr i zasobów środowiska w sposób pozwalający na realizację własnych celów tych polityk. Mimo to, takie nastawienie do polityki ekologicznej rzadko kiedy będzie skłaniać do minimalizowania w ramach innych polityk tendencji do nadmiernego zużywania zasobów i walorów środowiska. W konsekwencji polityka ekologiczna będzie tworzyć coraz silniejsze przeszkody i ograniczenia w stosunku do takiego modelu rozwoju sektorów.

${ }^{1}$ Wiele przykładów dobrych praktyk stosowania tych mechanizmów do różnych systemów decentralizacji zarządzania środowiskiem przedstawiono w opracowaniu: [Mazur, 2011]. 
Relacje polityk sektorowych do polityki ekologicznej mogą być jednak nacechowane gotowością do współpracy. Szczególnie powinno mieć to miejsce w dziedzinie ustalania celów - zbieżnych z celami polityki ekologicznej oraz ustalania mechanizmów korzystania z dóbr i zasobów środowiska. Te ostatnie powinny odpowiadać rynkowym realiom funkcjonowania sektorów. Konieczna jest więc postawa kooperacji polityki ekologicznej z politykami sektorowymi w wyznaczaniu celów i tworzeniu mechanizmów rynkowego dostępu do zasobów i walorów środowiska wykorzystywanych w bieżącym funkcjonowaniu i rozwoju sektorów. Podstawą takiej kooperacji może być zarówno ujęcie sektorowe, jak i produktowe.

Rynkowa orientacja z zastosowaniem podejścia kooperacyjnego wynika także z faktu odchodzenia od waskich programów rozwojowych na rzecz rozwiązań zintegrowanych, choć integracja ta dotyczy kwestii problemowych w skali całej gospodarki. Tym samym polityka ekologiczna nie może rozpatrywać działania poszczególnych sektorów z osobna i traktować je niejednakowo. Owo niedyskryminujące podejście wymaga stosowania jednakowych zasad i mechanizmów, niezależnie od: podmiotów, branż czy sektorów. Takie podejście można realizować w warunkach orientacji rynkowej.

\section{Postawa obserwacji}

Nie wszystkie sektory i rodzaje działalności cechuje wysoka uciążliwość dla środowiska czy też wysoki poziom zasobochłonności. Jest to typowe dla działalności usługowej, na przykład: bankowości, handlu detalicznego, turystyki albo telekomunikacji. Również wiele dziedzin współczesnego przemysłu rozwija się w sposób mało ingerujący w środowisko, na przykład przemysł elektroniczny lub narzędziowy. Wobec tych rynków polityka ekologiczna może stosować postawę obserwacji pasywnej. Powinna ona polegać na wyznaczeniu punktów kontrolnych - ram rozwoju rynku, na poziomie których ryzyko powstawania negatywnych zmian w środowisku nie istnieje lub jest akceptowalnie małe. Obserwacji moga podlegać: skala rozwoju rynku, strumienie zasobów środowiskowych wchodzące na rynek, skala przekształceń środowiska w wyniku działania rynku bądź wielkość negatywnych skutków środowiskowych. Jeśli funkcjonujące czy rozwijające się rynki nie przekraczają wyznaczonych ram, to nie ma powodu do podejmowania działań korygujących przez politykę ekologiczna. Jeżeli ramy zostają przekroczone, to polityka ekologiczna może w różny sposób oddziaływać na zmniejszenie uciążliwości funkcjonowania rynku dla środowiska. Może działać doraźnie, na przykład za pomocą narzędzi administracyjnych, ale może również stosować narzędzia rynkowe.

\section{Postawa stymulacji}

Możliwa jest równocześnie stymulacja lub wspieranie prośrodowiskowego przekształcania rynku. Polega to na stwarzaniu warunków do rozwoju rynku korzystniejszego dla środowiska. Podstawa jest istnienie lepszych ekologicznie alternatyw. Postawa tego typu może być zastosowana w dwóch sytuacjach. 
Pierwsza polega na przekształcaniu rynku w kierunku zniechęcania do nabywania towarów uciążliwych ekologicznie, gdy są towary mniej uciążliwe. Przykładem może tu być nakładanie obciążeń na użytkowanie pojazdów z silnikiem spalinowym o przestarzałej konstrukcji po to, by popyt przenosił się na rynek pojazdów o konstrukcji nowoczesnej, a także z silnikiem hybrydowym albo elektrycznym. Innym przykładem tego typu jest nakładanie obciążeń na użytkowanie opakowań jednorazowych po to, by wykorzystywać opakowania wielokrotnego użytku lub jednorazowe biodegradowalne.

Druga sytuacja dotyczy stwarzania zachęt do rozwoju określonego typu produktów, usług bądź procesów. Oddziaływanie jest skierowane na rozwój rynku produktów, przyjaznych ekologicznie. Instrumentami takiego oddziaływania mogą być zachęty: finansowe, kredytowe, fiskalne $\mathrm{i}$ inne, które uzyskują nabywcy produktów mniej uciążliwych ekologicznie. Przykładem moga być: ulgi pożyczkowe lub kredytowe dla nabywców instalacji solarnych, zwolnienia $z$ opłat za parkowanie w centrum miast dla użytkowników pojazdów elektrycznych, preferencje przy modernizacji instalacji przemysłowych o lepszych parametrach proekologicznych itp.

\section{Postawa ignorowania}

Ignorowanie przez politykę ekologiczną odnosi się do kwestii ekologicznych oddziaływań rynku lub tworzenia rynku związanego z realizacją celów polityki ekologicznej. Postawa ignorowania pozostawia problem optymalizacji ilości i jakości dóbr środowiskowych w wyborach podmiotów. Postawa taka może być konsekwencja założenia, że podmioty racjonalnie działają na rynku. Ich wybory nacechowane racjonalnością nie powinny więc prowadzić do nadmiernej eksploatacji zasobów środowiska bądź do przekraczania jego pojemności asymilacyjnej. Postawa ignorancji może także być następstwem niewiedzy osób odpowiedzialnych za politykę ekologiczna, braku dostatecznej i prawdziwej informacji, nieumiejętności przewidywania skutków działań podmiotów swobodnie decydujących o skali działań w środowisku itp.

\section{Postawa zaniechania}

Postawa zaniechania występuje w każdej polityce. Jest aktem świadomym, wynikającym z racjonalnego wyboru decydentów. Wiąże się z decyzją o wycofaniu się z działania w przekonaniu, że nie spowoduje to negatywnych skutków w stosunku do osiągania celów polityki. W przypadku polityki ekologicznej postawa zaniechania wobec rynku oznacza nieprzyjęcie innej z, wymienionych wcześniej, postaw (oprócz postawy ignorowania). Postawę zaniechania uzasadnia nadzieja na to, że podmioty same podejmą decyzję o utworzeniu rynku i że rynek ten ureguluje kwestie korzystania z zasobów albo że działające rynki nie będą negatywnie oddziaływać na środowisko. Ponadto, usprawiedliwieniem jest to, że w polityce ekologicznej są stosowane inne - niekoniecznie rynkowo zorientowane - formy regulacji ${ }^{2}$.

\footnotetext{
${ }^{2}$ Więcej na ten temat w: [Graczyk, 2013].
} 


\section{Polityka ekologiczna na rzecz zrównoważonej produkcji i konsumpcji}

Zintegrowane podejście do propagowania zrównoważonej konsumpcji i produkcji oraz zrównoważonej polityki przemysłowej jest obecne w Unii Europejskiej i na arenie międzynarodowej. W listopadzie 2013 roku został przyjęty VII ogólny unijny program działań w zakresie środowiska do 2020 roku (7EAP - 7th Environment Action Programme) pod nazwą Dobra jakość sycia z. unsgglednieniem ograniczeń naszej planety. Program ten ma zwiększyć wkład polityki ochrony środowiska w przechodzenie na gospodarkę zasobooszczędną i niskoemisyjna, w której kapitał naturalny jest chroniony i wzmacniany przy równoczesnej ochronie zdrowia i dobrostanu obywateli [Decyzja Parlamentu Europejskiego i Rady Nr 1386/2013/UE z dnia 20 listopada 2013 roku..., 2013, s. 171].

Polityka ekologiczna może uczestniczyć w tworzeniu i realizacji przedsięwzięć z tego zakresu zakrojonych na szeroką skalę. Do takich należy budowa i wdrożenie zintegrowanej polityki produktowej. Jej główną przesłanką jest powiązanie poprawy stylu życia $\mathrm{i}$ wzrostu dobrobytu, na które często bezpośrednio wpływają produkty w różny sposób związane z ochroną środowiska [Komunikat Komisji dla Rady i Parlamentu Europejskiego..., 2003, s. 2].

W polityce takiej problem oddziaływań na środowisko jest traktowany w sposób zintegrowany, odnoszący się do całego cyklu życia produktu. Podejście to różni się od tradycyjnie pojmowanej polityki ekologicznej, w której często działania były koncentrowane na określonych fazach cyklu życia produktu, zwykle na fazie produkcji i fazie poużytkowej. Tym samym uwzględniano skutki, a nie przyczyny. Tymczasem postęp w rozwiązywaniu problemów także można osiagnać, gdy nie dopuści się do powstawania przyczyn lub je odpowiednio wymodeluje. Działania zmniejszające negatywny wpływ produkcji i konsumpcji na środowisko moga być podejmowane na takim etapie cyklu życia produktu, na którym najefektywniej kosztowo zostanie zmniejszone wykorzystanie zasobów i oddziaływanie na środowisko.

Wymienia się pięć podstawowych zasad, do których odwołuje się zintegrowane podejście produktowe: myślenie w kategoriach cyklu życia produktu, współdziałanie z rynkiem, zaangażowanie uczestników, kontynuowanie poprawy, zróżnicowanie instrumentów polityki [Komunikat Komisji dla Rady i Parlamentu Europejskiego..., 2003, s. 5-6].

Polityka ekologiczna ma tu możliwość zastosowania całego spektrum instrumentów. Jednak ze względu na to, że podstawą decyzji angażujących się podmiotów powinny być działania dobrowolne, oparte na korzyściach ekonomicznych, naturalne wydaje się wykorzystywanie głównie instrumentów o charakterze rynkowym. Możliwe jest także sięganie do rozwiązań o zasięgu międzynarodowym, na przykład związanych z rynkowymi mechanizmami regulacji ochrony klimatu czy też ochrony zasobów przyrody.

Polityka ekologiczna może również służyć podejmowaniu licznych działań w celu ekologizacji konsumpcji. Według D. Kiełczewskiego [Kiełczewski, 2008, s. 60], trwałość konsumpcji oznacza, że utrwala się taki kształt jej procesów, który zapewnia maksymalizację poziomu życia w nieograniczonym czasie. Zasadnicze znaczenie dla 
jej osiagania miałyby takie sposoby wspierania rozwoju rynków produktów, które w istocie stanowią o przebudowie sytemu produkcji i konsumpcji na cele ekologiczne. Są to przede wszystkim: zintegrowana polityka produktowa oraz przebudowa postaw konsumenckich. Działania podejmowane przez politykę ekologiczna w tej sferze powinny w większym stopniu orientować się na monitorowanie i przekształcanie rynków.

Bieżąca polityka ekologiczna powinna wypracować kryteria i mechanizmy, którymi musi posługiwać się względem innych: polityk, programów i strategii, w tym:

- mechanizm akceptowania celów ekologicznych generowanych przez inne polityki (np. w odniesieniu do rolnictwa ekologicznego);

- mechanizm akceptowania celów wygenerowanych przez stronę rynkowa (produkty ekologiczne, rolnicze produkty żywnościowe itp.);

- mechanizm / postawa życzliwego tolerowania i wspierania rozwoju rynków o profilu ekologicznym akceptowanym przez politykę ekologiczna, spełniających podstawowe cele polityki ekologicznej (np.: kosmetyki ekologiczne, produkty fair trade);

- mechanizm wygaszania rynków - przyspieszania obumierania niektórych rynków (np.: rynek futer i odzieży z dzikich zwierząt, rynek jednorazowych naczyń z tworzyw sztucznych).

Powyższe propozycje wskazują na bogate możliwości zastosowania różnych postaw polityki ekologicznej w stosunku do szerokiego problemu wspierania proekologicznej produkcji i konsumpcji.

\section{Podsumowanie}

Generalną zasada postępowania polityki ekologicznej w sferze wspierania rozwoju rynków o profilu ekologicznym powinno być stosowanie takich regulacji, które maja wpływ na rynki produktów bardziej przyjaznych środowisku. Głównie reguluje się sposób tworzenia i korzystania z produktów, ale nie sam rynek.

Uwarunkowania związane ze zrównoważonym rozwojem oraz presja na poprawę efektywności i konkurencyjności gospodarki w długofalowej perspektywie będą wywierać coraz większy wpływ na wdrażanie rozwiązań rynkowych w polityce ekologicznej. Kierunek ten jest zgodny z ogólną ideą rozwoju gospodarki rynkowej.

\section{Literatura}

Decyzja Parlamentu Europejskiego i Rady nr 1386/2013/UE z dnia 20 listopada 2013 roku w sprawie ogólnego unijnego programu dzৃiatan w żakresie środowiska do 2020 roku. Dobra

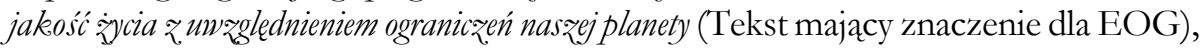
Dz.U. L 354 z 28.12.2013.

Graczyk A., 2013, Instrumenty rynkowe polityki ekologicznej, Teoria i prakty)ka, Wydawnictwo Uniwersytetu Ekonomicznego we Wrocławiu, Wrocław. 
Kiełczewski D., 2008, Konsumpcja a perspektyny zrównoważonego rožwoju, EKOPress, Bydgoszcz.

Komunikat Komisji dla Rady i Parlamentu Europejskiego. Zintegrowana Polityka Produktowa. Wykorsystywanie podejścia środowiskowego opartego na analizie cyklu syccia produktu, Komisja Wspólnot Europejskich, Bruksela, 18.06.2003 rok, COM (2003), 302 wersja ostateczna.

Mazur E., 2011, Environmental Enforcement in Decentralised Governance Systems: Toward a Nationwide Level Playing Field, OECD Environment Working Papers, nr 34, OECD Publishing, http://dx.doi.org/10.1787/5kgb1m60qtq6-en (data wejścia: 20.10.2014). Środowisko Europy 2015 - Stan i prognosy: Synteza, 2015, Europejska Agencja Środowiska, Kopenhaga. 